\title{
MEMAHAMI PARADIGMA PENDIDIKAN SENI
}

\author{
ALFA KRISTANTO ${ }^{1}$
}

\begin{abstract}
Understanding the paradigm of art education can help in understanding the essence of art education. Diversity paradigm can make the difference of interest in understanding the art of holistic education. Faced with the fact of diversity in the understanding of art education it is important to understand the paradigm of arts education together. Starting two views on arts education is education in the arts and education through art that led to the understanding of the general paradigm that continues to be able to understand art education.
\end{abstract}

Kata kunci : Paradigma, Pendidikan Seni, Karya Seni, Budaya, 


\section{PENDAHULUAN}

$\mathrm{D}^{-1}$ ua pandangan tentang pendidikan seni yaitu pendidikan seni sebagai pendidikan keterampilan siswa harus menguasai sejumlah keterampilan seni (pendidikan dalam seni), pandangan selanjutnya yaitu keterampilan berkarya seni yang sampai layak jual itu tidak penting tetapi cukup diberikan sejumlah pengalaman belajar tentang berkarya seni sebagai bagian dari pendidikan secara keseluruhan (pendidikan melalui seni).

Pendekatan pendidikan dalam seni ini pada awalnya dikemukakan oleh golongan esensialis bahwa secara hakiki seni sebagai materi atau disiplin ilmu perlu dan penting diberikan kepada anak didik. Keahlian menggambar, melukis, mematung, menari, musik, teater perlu ditanamkan kepada anak dalam kerangka pengembangan dan pelestarian kesenian yang ada. Kesenian yang adi luhung perlu dikenali, dipelajari agar dapat dijaga, dikembangkan dan dilestarikan. Pendekatan pendidikan dalam seni sejalan dengan pandangan pendidikan sebagai proses inkulturasi (proses pembudayaan) yang dilakukan untuk mewariskan/menanamkan nilai-nilai budaya antargenerasi. Pendekatan ini disadari atau tidak telah diterapkan di lingkungan keluarga (perajin-perupa), melaui pelaziman, meniru, internalisasi.

Pendekatan pendidikan melalui seni sangat penting dan jelas peranannya dapat diamati pada jenjang pendidikan dasar dan prasekolah. Sebagai contoh ketika guru sampaikan konsep penjumlahan digunakan dengan gambar. Bilangan dua ditambah tiga dapat ditampilkan dalam gambar dua jeruk dalam satu kelompok dan tiga jeruk dalam kelompok lainnya atau bisa bentuk gambar yang lain. Keterampilan gambar dijadikan alat atau sarana berhitung. Dengan demikian siswa belajar dengan seni (education with art). Pelaksanaan pendekatan pendidikan melalui seni ini lebih menekankan pada segi proses daripada hasil. Sasaran belajar pendidikan seni di sekolah umum tidak untuk jadikan anak didik pandai menggambar, melukis, atau mematung (jadi seniman), melainkan sebagai wahana berekspresi dan berimajinasi, berkreasi, berekreasi, dan berapresiasi. 


\section{PEMBAHASAN}

\section{Pengertian Paradigma}

Ada beberapa pembanding pengertian paradigma yaitu, seperangkat konsep yang berhubungan satu sama lain secara logis membentuk sebuah kerangka pemikiran yang berfungsi untuk memahami, menafsirkan, dan menjelaskan kenyataan dan atau masalah yang dihadapi. Pengertian lain yaitu kumpulan tata nilai yang membentuk pola pikir seseorang sebagai titik tolak pandangannya sehingga akan membentuk citra subjektif seseorang mengenai realita dan akhirnya akan menentukan bagaimana seseorang menanggapi realita itu. Menurut Kamus Besar Bahasa Indonesia, paradigma merupakan sebuah kerangka berpikir. Secara etimologis, paradigma berarti model teori ilmu pengetahuan atau kerangka berpikir, sedangkan secara terminologis, paradigma berarti pandangan mendasar para ilmuwan tentang apa yang menjadi pokok persoalan yang semestinya dipelajari oleh suatu cabang ilmu pengetahuan. Paradigma dalam disiplin intelektual adalah cara pandang seseorang terhadap diri dan lingkungannya yang akan mempengaruhinya dalam berpikir (kognitif), bersikap (afektif), dan bertingkah laku.

Penulis memberikan pengertian paradigma yaitu konsep berpikir seseorang terhadap masalah yang ada sehingga menghasilkan kerangka berpikir seseorang untuk menyelesaikan masalah yang dihadapi. Konsep berpikir didapat dari munculnya ide seseorang terhadap suatu masalah sehingga dilakukan pengamatan masalah dan muncul strategi untuk menyelesaikan masalah yang ada. Beberapa hal yang muncul dalam komponen paradigma yaitu asumsi dasar, nilai-nilai, masalah, model, konsep-konsep, metode penelitian, metode analisis, hasil analisis atau teori, representasi atau etnografi. Komponen paradigma ini menolong seseorang untuk menemukan ideologi sebuah paradigma.

\section{Pengertian Pendidikan Seni}

Memahami pendidikan seni terdapat dua hal yang perlu dimengerti yaitu pendidikan dan seni.

\section{Pengertian Pendidikan}

Berdasarkan rujukan resmi Undang-undang Republik Indonesia Nomor 2 Tahun 1989 tentang Sistem Pendidikan Nasional ; Pendidikan adalah usaha 
sadar untuk menyiapkan peserta didik melalui kegiatan bimbingan, pengajaran, dan/atau latihan bagi peranannya di masa yang akan datang (Soehardjo, 2012 : 13)

Pendidikan dalam bahasa Yunani disebut paedagogy yang bermakna "anak yang pergi dan pulang sekolah diantar seorang pelayan". Pelayan yang mengantar dan menjemput anak tersebut disebut paedagogos. Pendidikan telah ada sejak adanya manusia karena manusia adalah makhluk yang mendidik (homo educandus) sekaligus yang dididik (homo educandum). Fenomena (gejala-gejala) mendidik dan dididik itulah yang disebut dengan pendidikan. Fenomena pendidikan melekat pada hakikat manusia. Di mana ada manusia maka di situ ada pendidikan. Pendidikan merupakan fenomena fundamental atau asasi dalam kehidupan manusia. Jadi pendidikan bukan hanya ada pada manusia/masyarakat modern, tetapi juga dalam kalangan primitif (Soegeng Ysh, 2013 : 13).

Kamus Besar Bahasa Indonesia memberikan pengertian pendidikan yaitu proses pengubahan sikap dan tata laku seseorang atau kelompok orang dalam usaha mendewasakan manusia melalui upaya pengajaran dan pelatihan (proses, cara, perbuatan mendidik).

Penulis memberikan pengertian pendidikan adalah kegiatan terstruktur yang melibatkan pendidik dan anak didik yang bertujuan menciptakan manusia yang berbudi pekerti baik. Terstruktur artinya bahwa kegiatan tersebut melalui perencanaan yang baik. Perencanaan ini bisa diartikan seperti pembuatan kurikulum, pemilihan tenaga pengajar, penelitian terhadap anak didik, dan evaluasi.

\section{Pengertian Seni}

Kamus Besar Bahasa Indonesia menjelaskan bahwa arti seni yaitu karya, keahlian membuat karya dan didalamnya mencakup seni rupa, seni tari, seni drama, seni musik. A.J Soehardjo menjelaskan hasil analisis bahwa seni adalah kegiatan berkesenian. Selanjutnya diuraikan bahwa kegiatan berkesenian itu terdiri dari dua jenis, kegiatan berkesenian yang dilandasi modus imitasi (meniru) dan yang dilandasi modus ekspresi.

Penulis memberikan pengertian bahwa seni adalah ekspresi perasaan dan kognitif manusia yang dituangkan melalui sebuah karya. Dalam hal ini seni sangat luas lingkupnya dan tidak terbatas pada seni rupa, seni tari, seni drama, seni musik, puisi masuk dalam seni, pembuatan keterampilan tangan misalnya pembuatan sepatu, sandal, tenunan kain sutra dan sebagainya juga masuk 
dalam seni. Batasan pembahasan dimaksudkan pada seni musik, seni rupa, seni tari, seni drama.

Istilah pendidikan seni mempunyai beberapa penafsiran maksud yaitu pendidikan mengenai seni, atau pendidikan dalam seni, atau pendidikan melalui seni. Di masyarakat muncul istilah pembanding yaitu Seni Pendidikan yang diartikan seni untuk pendidikan. Penulis memberikan pemahaman mengenai arti pendidikan seni adalah pendidikan melalui seni atau seni sebagai media didalam pendidikan.

Perpaduan pengertian pendidikan dan seni, maka pengertian hakiki pendidikan seni adalah usaha sadar untuk menyiapkan peserta didik melalui kegiatan bimbingan, pengajaran dan atau latihan agar menguasai kemampuan berkesenian sesuai dengan peran yang harus dimainkannya (Soehardjo, 2012 : 13). Ada dua peran yang dapat dimainkan, pertama menularkan keterampilan seni, dan yang kedua memfungsi-didikan seni (Read, 1945 dan Wickiser, 1974).

Tesis Plato tentang Pendidikan Seni yang terkenal: "that art should be the basis of education "(seni seharusnya menjadi dasar pendidikan). Tesis ini menunjukkan bahwa seni memiliki peran dan fungsi yang penting bagi pendidikan secara umum. Dalam konteks ini seni dipandang sebagai alat atau sarana untuk mencapai sasaran atau tujuan pendidikan. Penggunaan istilah pendekatan ini disebut dengan " education through art". Dewey mengatakan: seni seharusnya menjadi alat untuk mencapai tujuan pendidikan, dan bukan untuk kepentingan itu seni sendiri. Dengan pendekatan ini pendidikan seni berkewajiban membantu ketercapaian tujuan pendidikan secara umum, yang memberikan keseimbangan rasional dan emosional, intelektualitas, dan sensibilitas dalam rangka bentuk kepribadian yang harmonis. Ini tepat diterapkan di sekolah-sekolah umum. Pendekatan pendidikan melalui seni amat penting dan jelas peranannya dapat diamati pada jenjang pendidikan dasar dan pra-sekolah. Sebagai contoh ketika guru menyampaikan konsep penjumlahan digunakan dengan gambar. Bilangan dua ditambah tiga dapat ditampilkan dalam gambar dua jeruk dalam satu kelompok dan tiga jeruk dalam kelompok lainnya atau bisa yang bentuk gambar yang lain. Keterampilan gambar dijadikan alat atau sarana berhitung. Dengan demikian siswa belajar dengan seni (education with art). Pelaksanaan pendekatan pendidikan melalui seni ini lebih menekankan pada segi proses daripada hasil. Sasaran belajar pendidikan seni di sekolah umum tidak untuk menjadikan anak didik pandai menggambar, melukis, atau mematung (jadi 
seniman), melainkan sebagai wahana berekspresi dan berimajinasi, berkreasi, berekreasi, dan berapresiasi (Triyanto, 2015).

Keberagaman pengertian pendidikan seni menunjukkan bahwa seni memiliki pengaruh kuat terhadap dunia pendidikan secara umum. Sedikit lembaga pendidikan yang memahami pentingnya pendidikan seni untuk menciptakan dunia pendidikan yang kreatif, inovatif, dan apresiatif. Masalah umum yaitu masih sempitnya ruang gerak seni dalam ranah pendidikan, mata pelajaran seni masih menjadi minoritas oleh para pembuat kurikulum.

\section{KESIMPULAN}

Fungsi pendidikan seni diantaranya yaitu sebagai pemenuhan kebutuhan anak dalam berekspresi, berapresiasi, berkreasi, berekreasi dan sebagai wahana ekspresivitas, sensitivitas, dan kreatifitas. Begitu banyakilmu pendidikan di dunia ini, tetapi masih sedikit yang melihat bahwa pendidikan seni itu sangat penting dalam dunia pendidikan. Karena metode belajar melalui seni mempermudah siswa untuk menangkap tujuan pembelajaran di sekolah sebagai contoh yaitu dalam penyampaian materi pelajaran. Pendidikan seni yaitu pendidikan melalui seni atau seni sebagai media dalam pendidikan. Seni mencakup aspek rasa, kognitif, dan tingkah laku dari masing-masing orang. Didalam seni sangat banyak ekspresi imajinasi seseorang sehingga hal itu menjadi pemicu kreatifitas setiap orang. Esensialisme menekankan bahwa pewarisan budaya sangat penting untuk dilestarikan pada dunia pendidikan. Siswa sebagai makhluk sosial sangat membutuhkan pengetahuan budaya sebagai konsekuensi hidup bermasyarakat. Hal tersebut sangat mendukung dalam pendidikan seni sebagai media pewarisan budaya bermasyarakat. Progresivisme mendukung siswa untuk dapat mengembangkan kreatifitasnya dalam pemenuhan kebutuhan pribadinya. Keaktifan anak didik akan mendorong perkembangan pengetahuannya dalam dunia pendidikan dengan memfungsikan guru sebagai seorang peneliti dan sekolah sebagai wadah atau laboratorium bagi siswa. Pendidikan seni membutuhkan keaktifan siswa untuk pengembangan pribadinya. Eksistensialisme menjadi pendorong siswa dapat menemukan berbagai kebutuhan pribadinya sebagai makhluk individu dan akan memberi pengaruh positif dalam pendidikan seni. Siswa sadar bahwa dirinya memiliki 
potensi untuk berkembang di berbagai bidang. Rekonstruktivisme mendukung pembentukan pola berpikir yang baik melalui pendidikan seni.

Seni mempunyai pengaruh kuat dalam dunia pendidikan untuk dapat menghasilkan ide-ide kreatif dari seorang pendidik dan mengembangkan pengetahuan budaya peserta didik. Sebuah paradigma akan menjadi penolong seseorang dalam memikirkan perkembangan pendidikan seni di Indonesia. Bagaimana seseorang berparadigma pendidikan seni? Memiliki wawasan yang luas terhadap pendidikan seni dapat membantu seseorang menemukan masalah dalam pendidikan seni. Pengamatan masalah pendidikan seni inilah yang akhirnya menjadikan seseorang menemukan ideologi dalam berparadigma.

Paradigma pendidikan seni yaitu konsep berpikir seseorang terhadap masalah dalam pendidikan seni, sehingga dapat terbentuk kerangka berpikir seseorang untuk melihat masalah dalam pendidikan seni dan akhirnya bisa menjadi solusi terhadap masalah dalam pendidikan seni. Fungsi paradigma pendidikan seni yaitu untuk menjaga keseimbangan ideologi pendidikan seni terhadap perkembangan dunia pendidikan pada umumnya. Paradigma pendidikan seni juga bisa menjadi inovasi kreatif dalam pengembangan budaya di sekitar. Berparadigma pendidikan seni dapat menghasilkan seseorang yang memiliki pemikiran secara divergen. Ketajaman melihat suatu permasalahan dalam pendidikan seni menjadi sumbangan ide munculnya paradigma pendidikan seni secara kreatif. 


\section{DAFTAR PUSTAKA}

Abdullah Idi.H, Jalaluddin.H, 2013, Filsafat Pendidikan, Manusia, Filsafat, dan Pendidikan

Cahyono, Agus, 2016, Materi perkuliahan Paradigma Pendidikan Seni. Semarang : PPS UNNES

Jazuli, M. 2008. Paradigma Kontekstual Pendidikan Seni.Semarang : Unessa University Press.

R. R, Tjetjep, 2016, Materi Seminar Antar Bangsa. Semarang : UNNES

Read, H. .1958. Education Through Art. London: Faber and Faber

Soegeng Ysh, A.Y, 2013, Filsafat Pendidikan suatu Pengembangan. Semarang : IKIP PGRI

Soehardjo, A.J, 2012, Pendidikan Seni Dari Konsep sampai Program. Malang : Universitas Negeri Malang

Sunarya Yaya, 2012, Filsafat Pendidikan

Suparli. 1983. Tinjauan Seni. Surabaya: SMKI.

Triyanto. 1983. "Pendidikan Seni Sebagai Proses Enkulturasi Nilai-nilai Budaya". dalamMedia FPBS IKIP Semarang Edisi 4 Th XVI 1983.

www.KamusBahasaIndonesia.org, diakses 16 Maret 2017 jam 09.05 WIB 